\title{
KEMAMPUAN MENGIDENTIFIKASI UNSUR-UNSUR PEMBANGUN TEKS PUISI SISWA KELAS VIII SMP NEGERI SATAP 10 KONAWE SELATAN
}

\author{
Intan Rosalinda ${ }^{1}$, Yunus ${ }^{2}$, Sumiman Udu ${ }^{3}$ \\ pbsi.fkip.uho@gmail.com \\ 1,2,3, Jurusan Pendidikan Bahasa dan Sastra Indonesia, \\ Fakultas Keguruan dan Ilmu Pendidikan, Universitas Halu Oleo \\ Kampus Hijau Bumi Tridharma Anduonohu, Kendari, Indonesia
}

\begin{abstract}
ABSTRAK
Masalah dalam penelitian ini adalah bagaimanakah kemampuan Mengidentifikasi Unsur-unsur Pembangun Teks Puisi Siswa Kelas VIII SMP Negeri Satap 10 Konawe Selatan?. Adapun tujuan yang ingin dicapai dalam penelitian ini adalah untuk mengetahui kemampuan siswa dalam mengidentifikasi unsur-unsur pembangun teks puisi siswa kelas VIII SMP Negeri Satap 10 Konawe Selatan. Metode yang digunakan dalam penelitian ini adalah metode deskriptif kuantitatif. Jenis penelitian ini tergolong dalam penelitian kelas. Berdasarkan hasil penelitian menunjukan bahwa dari 45 orag siswa yang menjadi responden penelitian, secara individual terdapat 21 orang siswa (46,67\%) masuk kategori mampu dan 24 orang siswa (53,33\%) masuk kategori belum mampu dalam mengidentifikasi unsur-unsur pembangun teks puisi. Secara klasikal kemampuan Mengidentifikasi unsur-unsur pembangun teks puisi siswa kelas VIII SMP Negeri Satap 10 Konawe Selatan masuk kategori belum mampu. Dikatakan demikian karena kemampuan siswa secara individual mencapai kemampuan minimal $70 \%$ hanya sebesar $46,67 \%$ belum mencapai kriteria kentutasan secara klasikal yaitu $85 \%$. Dilihat dari tingkat kemampuan siswa bahwa dari kedelapan komponenen yang menjadi aspek penilain yaitu pada aspek tema, amanat, majas, irama, kata konotasi, kata berlambang, dan pengimajian tidak tuntas secara klasikal karena persentasenya tidak mencapai kriteria kentutasan klasika yaitu $85 \%$.
\end{abstract}

Kata Kunci : kemampuan mengidentifikasi; teks puisi; unsur pembangun teks puisi 


\section{PENDAHULUAN}

Pada hakikatnya pembelajaran sastra bertujuan untuk meningkatkan kemampuan mengapresiasi sastra, yang berarti setelah mempelajari sastra, siswa diharapkan mampu mengenal, memahami, menghayati, dan menghargai karya sastra. Sebagai cermin yang menunjukan suatu simbol kemajuan dalam kehidupan suatu bangsa.

Dalam kegiatan pembelajaran puisi, siswa diarahkan untuk memahami teori yang berhubungan dengan unsur-unsur pembangun puisi, seperti tema,amanat, perasaan penyair, majas, irama, kata konotasi, kata berlambang, dan pengimajian. Pembelajaran sastra khususnya puisi tidak dapat diabaikan begitu saja, tetapi perlu ditanamkan kepada siswa, agar siswa mendapat pengetahuan yang luas tentang pemahaman dan penerapannya, sehingga siswa mempunyai sikap positif terhadap karta sastra (puisi).

Pembelajaran puisi di kelas VIII SMP Negeri Satap 10 Konawe Selatan pada prinsipnya bertujuan untuk mengembangkan yang ada dalam potensi dalam diri siswa sesuai dengan kemauannya. Pengenalan kemampuan dan batas kemauan siswa yang dimaksudkan untuk dapat memperkenalkan serta mempertahankan dirinya dalam hidup bermasyarakat. Selain itu pembelajaran puisi di sekolah menengah pertama dimaksudkan untuk mengembangkan kepekaan siswa terhadap nilai-nilai indrawi, nilai hakiki, nilai afektif, nilai sosial, ataupun gabungan dari keseluruhnnya yang tersebar dalam ruang-ruang hidup masyarakatnya.

Berdasarkan kurikulum 2013, dalam pembelajaran menyimpulkan isi puisi terdapat salah satu materi pembelajaran yang dipelajari siswa yaitu : mengidentifikasi unsur-unsur pembangun teks puisi, SMP di kelas VIII semester satu. Materi tersebut tertera pada silabus pembelajaran bahasa Indonesia yaitu pada Kompetensi Dasar 3.7 mengidentifikasi unsur-unsur pembangun teks puisi yang diperdengarkan atau di baca. Indikator pencapaian kompetensi setelah mempelajari materi tersebut adalah siswa diharapkan mampu mengidentifikasi unsurunsur pembangun teks puisi yang diperdengarkan atau dibaca.
Peneliti memilih kemampuan mengidentifikasi unsur- unsur pembangun teks puisi karena materi tersebut tertuang dalam kurikulum 2013 dan termuat dalam silabus bahasa Indonesia dan buku bahasa Indonesia kelas VIII SMP/MTs yang terdapat pada semester satu, dengan kompetensi dasar 3.7 dasar mengidentifikasi unsur- unsur pembangun teks puisi yang diperdengarkan/dibaca. Sebagai tempat penelitian didasari atas pertimbangan, siswa kelas VIII SMP Negeri Satap 10 Konawe Selatan telah mempelajari mengidentifikasi unsur- unsur pembangun teks puisi sesuai dengan kurikulum 2013 dan rasa keingintahuan peneliti untuk mengetahui kemampuan siswa dalam mengidentifikasi unsur- unsur pembangun teks puisi yang diperdengarkan/dibaca

Dari hasil obesevasi yang dilakukan, tujuan penelitian yaitu untuk mengukur kembali tingkat keberhasilan siswa dengan KKM yang telah ditentukan di SMP Negeri Satap 10 Konawe Selatan dan untuk mengetahui kemampuan siswa dalam menentukan unsur- unsur pembangun puisi. Disediakan sebuah teks puisi dan kemudian siswa menentukan unsur- unsur pembangun puisi dari teks tersebut.

Berdasarkan uraian tersebut, peneliti tertarik untuk melakukan penelitian yang berjudul "kemampuan menentukan unsur-unsur pembangun puisi siswa kelas VIII SMP Negeri Satap 10 Konawe Selatan".

Berdasarkan uraian latar belakang yang telah dipaparkan di atas, maka yang menjadi rumusan masalah dalam penelitian ini adalah bagaimanakah kemampuan mengidentifikasi unsur-unsur pembangun teks puisi siswa Kelas VIII SMP Negeri Satap 10 Konowe Selatan?

Tujuan penelitian ini adalah untuk mendeskripsikan kemampuan mengidentifikasi unsur-unsur pembangun teks puisi siswa Kelas VIII SMP Negeri Satap 10 konawe Selatan.

Manfaat yang dapat diperoleh dalam penelitian ini adalah :

1. Sebagai bahan informasi bagi guru bahasa Indonesia di SMP/MTs khususnya SMP Negeri Satap 10 Konawe Selatan tentang 
mengidentifikasi pembangun teks puisi siswa

2. Penelitian ini dapat dijadikan sebagai bahan informasi bagi siswa tentang kemampuan mengidentifikasi unsur-unsur pembangun teks puisi siswa.

3. Sebagai bahan acuan bagi penelitian selanjutnya tentang menulis puisi khususnya pada aspek kemampuan mengidentifikasi unsur-unsur pembangun teks puisi siswa yang belum dikaji.

Berdasarkan manfaat penelitian diatas, ruang lingkup dalam penelitian ini adalah terbatas pada kemampuan mengidentifikasi unsur-unsur pembangun teks puisi siswa dengan memperhatikan aspek sebagai berikut : tema, amanat, rasa, majas, irama, kata konotasi, kata berlambang dan pengimajian.

Menurut (Dalman, 2016 : 3) menulis merupakan kegiatan komunikasi berupa penyampaian pesan (informasi) secaratertulis kepada pihak lain dengan menggunakan bahasa tulis sebagai alat atau medianya. Dan menulis juga merupakan sebuah proses kreatif menuangkan gagasan dalam bentuk bahasa tulis dalam tujuan misalnya, memberi tahu, meyakinkan, atau menghibur.

Menulis sebagai salah satu keterampilan berbahasa tentu memiliki tujuan. Sebuah tulisan memiliki maksud penyampaian. Saat ini, sebagai satu keterampilan, menulis sangat dibutuhkan banyak orang. Secara umum, Tarigan (dalam Said, 2017 : 4-6) mengungkapkan bahwa tujuan menulis adalah sebagai berikut.

1. Tulisan bertujuan untuk memberitaukan atau mengajar yang disebut dengan wacana informatif.

2. Tulisan yang bertujuan untuk menyakinkan atau mendesak yang disebut dengan wacana persuasif.

3. Tulisan yang bertujuan untuk menghibur atau menyenangkan atau yang mengandung tujuan estetik yang disebut dengan wacana kesastraan.

4. Tulisan yang mengespresikan perasaaan dan emosi yang kuat atau berapi-api yang disebut dengan wacana ekspresif.
(Tarigan, 2013 : 23-24) setiap jenis tulisan mengandung beberapa tujuan, karena tujuan itu sangat beraneka ragam bagi penulis yang belum berpengalaman ada baiknya memperhatikan kategori dibawah ini :

1. memberitahukan atau mengajar;

2. meyakinkan atau menyenangkan;

3. menghibur atau menyenangkan; dan

4. mengutarakan atau mengespresikan perasaan dan emosi yang berapiapi.

(Dalman, 2016: 6) mengemukakan bahwa menulis memiliki banyak manfaat yang dapat dipetik dalam kehidupan ini, diantaranya adalah :

1. peningkatan kecerdasan;

2. pengembangan daya inisiatif dan kreativitas;

3. penumbuhan keberanian;

4. pendorongan kemauan dan kemampuan mengumpulkan informasi.

(Pradopo, 2017: 12) menyatakan bahwa puisi adalah ekspresi kreatif (yang mencipta), sedang prosa itu ekspresi konstruktif. (Juanda, 2017: 97) mengatakan bahwa puisi adalah bentuk karya sastra yang menggunakan kata-kata indah dan padat makna. Sedangkan menurut (Waluyo, 2002: 1) mengatakan bahwa puisi adalah karya sastra dengan bahasa yang dipadatkan,dipersingkat, dan diberi irama dengan bunyi yang padudan pemilihan katakata kias (imajinatif).

Hakikat puisi adalah curahan hati yang diungkapkan penyair dalam puisi. Hakikat puisi disebut juga isi puisi. Hakikat puisi bukan terletak pada bentuk formalnya meskipun bentuk formal itu penting. Puisi baru (modern) tidak terikat pada bentuk formal, tetapi disebut puisi juga. Ada tiga aspek yang perlu diperhatikan untuk mengerti hakikat puisi yaitu : (1) Sifat seni atau fungsi seni, (2) Kepaduan,dan (3) ekspresi tidak langsung.

Unsur- unsur puisi meliputi majas, irama, kata-kata konotasi, dan kata- kata berlambang dan pengimajinasian. Unsur tersebut berfungsi sebagai unsur fisik puisi, yakni unsur yang dapat dikenali langsung oleh pembaca karena sifatnya tersurat. Disamping itu. ada pula unsur batin, yakni 
unsur yang tersembunyi dibaik unsur- unsur fisik. Untuk menemukannya kamu harus memahami puisi itu dengan baik. Dengan cara demikian, akan tersingkap unsur batin, Pembelajaran kurikulum 2013 memiliki muatan pendidikan karakter yang terintegrasi dalam SKL, KI-KD, Standar Proses dan Standar Penilaian. Pendidikan karakter tersirat dalam Kompetensi Inti (KI) sikap spiritual dan sikap sosial yang dikenal dengan KI-1 dan KI-2.

Berdasarkan silabus dan sesuai dengan kurikulum 2013 yang diterbitkan oleh Depdiknas, pembelajaran mengidentifikasi unsur-unsur pembangun puisi di SMP kelas VIII pada semester satu. Dalam silabus tersebut, siswa diharapkan dapat terampil dalam mengidentifikasi unsur-unsur pembangun teks puisi. Pembelajaran mengidentifikasi unsur-unsur pembangun teks puisi tercantum dalam silabus kurikulum 2013 yang diberi kompetensi inti dan kompetensi dasar. Kompetensi inti pada mata pembelajaran bahasa Indonesia berisi 4 kompetensi antara lain : (1) Menghargai dan menghayati ajaran agama yang dianutnya, (2) serta menghargai dan menghayati perilaku jujur, displin, santun, percaya diri, peduli, dan bertanggung jawab dalam berinteraksi secara efektif sesuai dengan perkembangan anak dilingkungan, keluarga, sekolah, masyarakat dan lingkungan alam sekitar, bangsa, negara, dan kawasan regional, (3) Memahami dan menerapkan pengetahuan factual, konseptual, procedural, dan metakognitif pada tingkat teknis dan spesifik sederhana berdasarkan rasa ingin tahunya tentang ilmu pengetahuan, teknologi, seni, budaya dengan wawasan kemanusian, kebangsaan dan kenegaraan terkait fenomena dan kejadian tampak mata, (4) Mencoba dan menyaji dan menalar dalam ranah konkret (menggunakan, mengurai, merangkai, memodifikasi, dan membuat) dan ranah abstrak (menulis, membaca, menghitung, menggambar, dan mengarang) sesuai dengan yang dipelajari di sekolah dan sumber lain yang sama dalam sudut pandang/teori

Jenis penelitian ini merupakan penelitian kelas karena dilakukan secara langsung di SMP Negeri Satap 10 Konawe Selatan sebagai tempat penelitian untuk mengumpulkan data sesuai dengan masalah penelitian.

Metode yang digunakan dalam penelitian ini adalah metode deskriptif kuantitatif menyajikan data-data yang ditemukan di lapangan yang berhubungan dengan kemampuan menentukan unsurunsur pembangun puisi siswa Kelas VIII SMPN Satap 10 Konawe Selatan yang selanjutnya diuraikan menggunakan angkaangka sesuai dengan prinsip statistik.

Populasi dalam penelitian ini adalah seluruh siswa Kelas VIII SMPN Satap 10 Konawe Selatan, dan sampel dalam penelitian ini menggunakan (total sampling), maka yang menjadi sampel penelitian dalam penelitian ini adalah keseluruhan populasi yang berjumlah 45 orang siswa.

Populasi tersebut berjumlah 45 siswa yang tersebar dalam 2 kelas dalam rincian sebagai berikut.

\section{Tabel 3.1}

Daftar Populasi Siswa Kelas VIII SMPN Satap 10 Konawe Selatan

\begin{tabular}{|l|l|l|}
\hline No. & Kelas & $\begin{array}{l}\text { Jumlah } \\
\text { siswa }\end{array}$ \\
\hline 1 & VIII $_{\mathrm{A}}$ & 23 \\
\hline 2 & $\mathrm{VIII}_{\mathrm{B}}$ & 22 \\
\hline \multicolumn{2}{|l|}{ Jumlah } & 45 \\
\hline
\end{tabular}

(Sumber Data : SMP Negeri Satap 10

Konawe Selatan)

Penelitian ini menggunakan instrument tes tertulis yang berbentuk esai yaitu kemampuan menentukan unsur-unsur pembangun puisi. Dalam instrument, siswa membaca dengan seksama puisi kemudian menjawab pertanyaan yang telah disediakan yang berkaitan dengan unsur-unsur pembangun puisi seperti tema, amanat, rasa, majas, irama, kata konotasi, kata berlambang, dan pengimajinasian.

Teknik pengumpulan data yang digunakan dalam penelitian ini adalah tes tertulis yaitu mengidentifikasi unsur-unsur pembangun teks puisi. Dalam proses pengumpulan data peneliti akan dibantu oleh guru Bahasa Indonesia di sekolah tempat peneliti mengadakan penelitian agar situasi dan kondisi tetap terjaga. Penelitian ini 
dilaksanakan pada tanggal 2 Desember 2020 semester satu.

Langkah yang dilakukan adalah sebagai berikut.

1. Mengecek kehadiran siswa.

2. Membagi lembar tugas, berfungsi sebagai alat pengumpul data dan digunakan untuk menulis unsur-unsur pembangun puisi.

3. Masing-masing siswa mengidentifikasi unsur-unsur pembangun teks puisi dalam waktu 80 menit

4. Hasil tulisan siswa dikumpulkan secara kolektif.

5. Memberikan penilaian terhadap hasil yang ditulis siswa dengan aspek yang telah ditentukan.

Penilaian penulisan mengidentifikasi unsur-unsur pembangun teks puisi dengan memperhatikan aspek sebagai berikut : tema, amanat, rasa , majas, irama, kata konotasi, kata berlambang, dan pengimajian. Untuk mengetahui tingkat kemampuan siswa kelas VIII SMPN Satap 10 Konawe Selatan dalam mengidentifikasi unsur-unsur pembangun teks puisi, peneliti berpedoman pada kriteria ketuntasan minimal (KKM) pembelajaran bahasa Indonesia yaitu 70 yang berlaku di SMP Negeri 10 Konawe Selatan. digunakan pedomanan ketuntasan belajar secara individual dan klasikal, yakni $70 \%$ keberhasilan individual atau mendapat minimal $70 \%$ (tuntas secara individual) dan $85 \%$ secara klasikal atau minimal $85 \%$ (tuntas secara klasikal) dari seluruh responden.

Adapun rumus yang digunakan untuk mencari nilai kemampuan individual adalah :

$\mathrm{KI}$

$\frac{\text { Jumlah skor yang diperoleh }}{\text { jumlah skor maksimal }} \times 100 \%$

Rumus yang digunakan untuk mencari nilai kemampuan klasikal adalah :
Menentukan

kemampuan mengidentifikasi unsur-unsur pembangun teks puisi dengan tolak ukur yang digunakan sebagai berikut :
Tabel 3.3

Rentang Kemampuan Siswa

\begin{tabular}{|l|l|l|}
\hline $\begin{array}{l}\text { Kategori } \\
\text { Kemamp } \\
\text { uan }\end{array}$ & $\begin{array}{l}\text { Renta } \\
\text { ng } \\
\text { Skor }\end{array}$ & $\begin{array}{l}\text { Peresntase Kema } \\
\text { mpuan }\end{array}$ \\
\hline Mampu & $\begin{array}{l}14- \\
20\end{array}$ & $70 \%-100 \%$ \\
\hline $\begin{array}{l}\text { Belum } \\
\text { Mampu }\end{array}$ & $1-13$ & $5 \%-65 \%$ \\
\hline
\end{tabular}

Berdasarkan tabel tersebut dapat dijelaskan sebagai berikut :

1.

ikategorikan mampu
ikasi unsur-unsur teks puisi jika mendapat skor 14-20 dengan presentase $70 \%$ sampai $100 \%$

2. Siswa dikategorikan tidak mampu mengidentifikasi unsur-unsur pembangun teks puisi jika mendapat skor 1-13 dengan presentase $5 \%$ sampai $65 \%$

\section{HASIL PENELITIAN}

2.1 Deskripsi Pelaksanaan Penelitian

Tabel 4.2

Presentase Keseluruhan Aspek penilaian Kemampuan

Mengidentifikasi Unsur-unsur Pembangun Teks Puisi Siswa Kelas VIII SMP Negeri Satap 10 Konawe

KK $100 \%$

Keterangan :

$\mathrm{KI}:$ Ketuntasan Individual

KK : Ketuntasan Klasikal

\section{Selatan}

\begin{tabular}{|c|c|c|c|c|}
\hline $\begin{array}{c}\text { N } \\
\text { o } \\
0 \%\end{array}$ & $\begin{array}{c}\text { Sko } \\
\mathbf{r}\end{array}$ & $\begin{array}{c}\text { Frekue } \\
\text { nsi } \\
\text { Siswa }\end{array}$ & $\begin{array}{c}\text { Present } \\
\text { ase }\end{array}$ & $\begin{array}{c}\text { Kateg } \\
\text { ori }\end{array}$ \\
\hline 1. & $\begin{array}{c}14- \\
20\end{array}$ & 21 & $46,67 \%$ & $\begin{array}{c}\text { Mamp } \\
\mathrm{u}\end{array}$ \\
\hline 2. & $\begin{array}{c}1- \\
13\end{array}$ & 24 & $53,33 \%$ & $\begin{array}{c}\text { Belum } \\
\text { mamp } \\
\mathrm{u}\end{array}$ \\
\hline
\end{tabular}


Berdasarkan tabel diatas, dapat diperoleh informasi bahwa diantara 45 orang siswa yang dijadikan sampel terdapat 21 orang siswa $(46,67)$ mampu dalam mengidentifikasi unsur-unsur pembangun teks puisi, dan 24 orang siswa $(53,33 \%)$ tidak mampu dalam mengidentifikasi unsur-unsur pembangun teks puisi.

$$
\text { Selanjutnya untuk }
$$
mengukur kemampuan mengidentifikasi unsur-unsr pembangun teks puisi siswa kelas VIII SMP Negeri Satap 10 Konawe Selatan secara klasikal maka digunakan rumus sebagai berikut.

$$
\begin{gathered}
\mathbf{K K}= \\
\text { Jumlah responden yang memperoleh presentase } \geq \mathbf{7 0} \% \\
\text { Jumlah sampel } \\
\mathbf{1 0 0} \% \\
=\frac{\mathbf{2 1}}{\mathbf{4 5}} \mathbf{x} \mathbf{1 0 0 \%} \\
=\mathbf{4 4 , 6 7 \%} \\
\text { Dengan demikian, kemampuan } \\
\text { mengidentifikasi } \quad \text { unsur-unsur } \\
\text { pembangun teks puisi siswa kelas VIII } \\
\text { SMP Negeri Satap 10 Konawe Selatan } \\
\text { dikategorikan tidak mampu secara } \\
\text { klasikal. Dikatakan tidak mampu karena } \\
\text { jumlah presentase kemampuan secara } \\
\text { klasikal yang diperoleh siswa adalah } \\
\text { 44.67\% dan belum mencapai persentase } \\
\text { kemampuan minimal secara klasikal } \\
\text { yang telah ditetapkan yaitu 85\%. }
\end{gathered}
$$

\begin{tabular}{|c|c|c|c|c|}
\hline $\begin{array}{l}\mathbf{N} \\
\mathbf{0}\end{array}$ & $\begin{array}{c}\text { Sko } \\
\text { r }\end{array}$ & $\begin{array}{c}\text { Frekue } \\
\text { nsi }\end{array}$ & $\begin{array}{c}\text { Present } \\
\text { ase }\end{array}$ & $\begin{array}{c}\text { Kateg } \\
\text { ori }\end{array}$ \\
\hline & & Siswa & & \\
\hline
\end{tabular}

\subsection{Deskripsi Kemampuan Mengidentifikasi Unsur-unsur Pembangun Teks Puisi Siswa Kelas VIII SMP Negeri Satap 10 Konawe Selatan pada Setiap Aspek Penilaian}

2.2.1 Deskripsi Kemampuan pada Aspek PenulisanTema

Tabel 4.4

Presentase Perolehan Siswa pada Aspek Penulisan Tema dalam Mengidentifikasi Unsur-unsur Pembangun Teks Puisi Siswa Kelas VIII SMP Negeri Satap 10 Konawe Selatan

\begin{tabular}{|c|c|c|c|c|}
\hline 1. & $\begin{array}{c}14- \\
20\end{array}$ & 25 & $55,56 \%$ & $\begin{array}{c}\text { Mamp } \\
\mathrm{u}\end{array}$ \\
\hline 2. & $\begin{array}{c}1- \\
13\end{array}$ & 20 & $44,44 \%$ & $\begin{array}{c}\text { Belum } \\
\text { mamp } \\
\mathrm{u}\end{array}$ \\
\hline
\end{tabular}

Berdasarkan tabel diatas dapat dilihat, dapat dilihat bahwa kemampuan siswa dari aspek penulisan tema dalam mengidentifikasi unsur-unsur pembangun teks puisi siswa kelas VIII SMP Negeri Satap 10 Konawe Selatan terdapat 25 orang siswa $(55,55 \%)$ dikatakan mampu dan 20 orang siswa $(44,44 \%)$ tidak mampu dalam mengidentifikasi unsur-unsur pembangun teks puisi.

$$
\text { Selanjutnya untuk }
$$
mengukur kemampuan siswa dari aspek penulisan tema dalam mengidentifikasi unsur-unsur pembangun teks puisi secara klasikal maka digunakan rumus sebagai berikut:

$$
\begin{aligned}
& K \mathrm{~K}= \\
& \underline{\text { Jumlah responden yang memperoleh presentase } \geq 70 \%} \mathbf{7 0} \\
& \text { Jumlah sampel } \\
& 100 \% \\
& =\frac{25}{45} \times 100 \% \\
& =\mathbf{5 5 , 5 6 \%}
\end{aligned}
$$

\subsubsection{Deskripsi Kemampuan pada Aspek Penulisan Amanat}

Tabel 4.6

Presentase Perolehan Siswa pada Aspek Penulisan Amanat dalam Mengidentifikasi Unsur-unsur Pembangun Teks Puisi Siswa Kelas 
VIII SMP Negeri Satap 10 Konawe Selatan

\begin{tabular}{|c|c|c|c|c|}
\hline $\begin{array}{c}\text { N } \\
\text { o }\end{array}$ & $\begin{array}{c}\text { Sko } \\
\mathbf{r}\end{array}$ & $\begin{array}{c}\text { Frekue } \\
\text { nsi } \\
\text { Siswa }\end{array}$ & $\begin{array}{c}\text { Present } \\
\text { ase }\end{array}$ & $\begin{array}{c}\text { Kateg } \\
\text { ori }\end{array}$ \\
\hline 1. & $\begin{array}{c}14- \\
20\end{array}$ & 5 & $11,11 \%$ & $\begin{array}{c}\text { Mamp } \\
\mathrm{u}\end{array}$ \\
\hline 2. & $1-$ & 40 & $88,89 \%$ & $\begin{array}{c}\text { Belum } \\
\text { mamp } \\
\mathrm{u}\end{array}$ \\
\hline
\end{tabular}

Berdasarlan tabel diatas, dapat dilihat bahwa kemampuan siswa dari aspek penulisan amanat dalam mengidentifikasi unsur-unsur pembangun teks puisi siswa kelas VIII SMP Negeri Satap 10 Konawe Selatan terdapat 5 siswa orang siswa $(11,11 \%)$ dikategorikan mampu dan 40 orang siswa $(88,89 \%)$ dikategorikan belum mampu.

Selanjut untuk mengukur kemampuan siswa dari aspek penulisan amanat dalam mengidentifikasi unsurunsur pembangun teks puisi secara klasikal maka digunakan rumus sebagai berikut.

$$
K \mathrm{~K}=
$$

$\underline{\text { Jumlah responden yang memperoleh presentase } \geq 70 \%} \mathbf{X}$

$$
\begin{aligned}
& \text { Jumlah sampel } \\
& 100 \% \\
= & \frac{5}{45} \times 100 \\
= & 11,11 \%
\end{aligned}
$$

Dengan demikian, bila dilihat kemampuan siswa pada aspek penilaian, yakni penulisan amanat dalam mengidentifikasi unsur-unsur pembangun teks puisi. kemampuan mengidentifikasi unsur-unsur pembangun teks puisi siswa kelas VIII SMP Negeri Satap 10 Konawe Selatan dikategorikan tidak mampu secara klasikal. Dikatakan tidak mampu karena kemampuan siswa mencapai $11,11 \%$ belum mencapai kriteria kemampuan secara klasikal yang telah ditetapkan yakni $85 \%$.

\subsubsection{Deskripsi Kemampuan pada Aspek Penilaian Rasa}

Tabel 4.8

Presentase Perolehan Siswa pada Aspek Penulisan Rasa dalam Mengidentifikasi Unsur-unsur Pembangun Teks Puisi Siswa Kelas VIII SMP Negeri Satap 10 Konawe Selatan

\begin{tabular}{|c|c|c|c|c|}
\hline $\begin{array}{c}\text { N } \\
\text { o }\end{array}$ & $\begin{array}{c}\text { Sko } \\
\mathbf{r}\end{array}$ & $\begin{array}{c}\text { Frekue } \\
\text { nsi } \\
\text { Siswa }\end{array}$ & $\begin{array}{c}\text { Present } \\
\text { ase }\end{array}$ & $\begin{array}{c}\text { Kateg } \\
\text { ori }\end{array}$ \\
\hline 1. & $\begin{array}{c}14- \\
20\end{array}$ & 24 & $53,33 \%$ & $\begin{array}{c}\text { Mamp } \\
\mathrm{u}\end{array}$ \\
\hline 2. & $1-$ & 21 & $46,67 \%$ & $\begin{array}{c}\text { Belum } \\
\text { Mamp } \\
\mathrm{u}\end{array}$ \\
\hline
\end{tabular}

Berdasarkan tabel diats, dapat dilihat bahwa kemampuan siswa dari aspek rasa dalam mengidentifikasi unsurunsur pembangun teks puisi siswa kelas VIII SMP Negeri Satap 10 Konawe Selatan terdapat 24 orang siswa $(53,33)$ dikategorikan mampu dan 21 orang siswa dikategorikan tidak mampu $(46,67 \%)$ dikategorikan belum mampu.

Selanjutnya untuk mengukur kemampuan siswa dari asspek rasa dalam mengidentifikasi unsur-unsur pembangun teks puisi secara klasikal maka digunakan rumus sebagai berikut.

$$
K \mathrm{~K}=
$$

Jumlah responden yang memperoleh presentase $\geq 70 \%$ Jumlah sampel $100 \%$

$$
\begin{aligned}
= & \frac{24}{45} \times 100 \% \\
= & 53,33 \%
\end{aligned}
$$

Dengan demikian, bila dilihat kemampuan siswa pada aspek penilaian, yakni suasana dalam mengidentifikasi unsurunsur pembangun teks puisi. Kemampuan mengidentifikasi unsur-unsur pembangun teks puisi siswa kelas VIII SMP Negeri Satap 10 Konawe Selatan dikategorikan tidak mampu secara klasikal. Dikatakan belum mampu karena kemampuan siswa hanya mencapai 53,33\% atau belum mencapai kriteria kemampuan secara klasikal yang ditetapkan yaitu $85 \%$. 


\subsubsection{Deskripsi Kemampuan pada Aspek Penulisan Majas}

Tabel 4.10

Presentase Perolehan Siswa pada Aspek Penulisan Majas dalam Mengidentifikasi Unsur-unsur Pembangun Teks Puisi Siswa Kelas VIII SMP Negeri Satap 10 Konawe Selatan

\begin{tabular}{|c|c|c|c|c|}
\hline $\begin{array}{c}\mathbf{N} \\
\mathbf{o}\end{array}$ & $\begin{array}{c}\text { Sko } \\
\mathbf{r}\end{array}$ & $\begin{array}{c}\text { Frekue } \\
\text { nsi } \\
\text { Siswa }\end{array}$ & $\begin{array}{c}\text { Present } \\
\text { ase }\end{array}$ & $\begin{array}{c}\text { Kateg } \\
\text { ori }\end{array}$ \\
\hline 1. & $\begin{array}{c}14- \\
20\end{array}$ & 7 & $15,56 \%$ & $\begin{array}{c}\text { Mamp } \\
\mathrm{u}\end{array}$ \\
\hline 2. & $1-$ & 38 & $84,44 \%$ & $\begin{array}{c}\text { Belum } \\
\text { mamp } \\
\mathrm{u}\end{array}$ \\
\hline
\end{tabular}

Berdasarkan tabel diatas, dapat dilihat bahwa kemampuan siswa dari aspek penulisan majas dalam mengidentifikasi unsur-unsur pembangun teks puisi kelas VIII SMP Negeri Satap 10 Konawe Selatan terdapat 30 orang siswa $(15,56 \%)$ dikategorikan mampu dan 17 orang siswa $(84,44 \%)$ dikategorikan belum mampu.

Selanjutnya untuk mengukur kemampuan siswa dari aspek penulisan majas dakam menentukan unsur-unsur pembangun puisi secara klasikal maka digunakan rumus sebagai berikut.

$$
K \mathbf{K}=
$$

$\underline{\text { Jumlah responden yang memperoleh presentase } \geq 70 \%} \mathbf{X}$

$$
\begin{aligned}
& \text { Jumlah sampel } \\
& 100 \% \\
= & \frac{7}{45} \times 100 \% \\
= & 15,56 \%
\end{aligned}
$$

Dengan demikian, bila dilihat kemampuan siswa pada aspek penilaian, yakni penulisan majas dalam mengidentifikasi unsur-unsur pembangun teks puisi. Kemamapuan mengidentifikasi unsur-unsur pembangun teks puisi kelas VIII SMP Negeri Satap 10 Konawe Selatan dikategorikan belum mampu secara klasikal. Dikatakan tidak mampu karena kemampuan siswa mencapai $15,56 \%$ belum mencapai kriteria kemampuan secara klasikal yang telah ditetapkan yaitu $85 \%$.

\subsubsection{Deskripsi Kemampuan pada Aspek Penulisan Irama}

Tabel 4.12

Presentase Perolehan Siswa pada Aspek Penulisan Irama dalam Mengidentifikasi Unsur-unsur Pembangun Teks Puisi Siswa Kelas VIII SMP Negeri Satap 10 Konawe Selatan

\begin{tabular}{|c|c|c|c|c|}
\hline $\begin{array}{c}\text { N } \\
\text { o }\end{array}$ & $\begin{array}{c}\text { Sko } \\
\mathbf{r}\end{array}$ & $\begin{array}{c}\text { Frekue } \\
\text { nsi } \\
\text { Siswa }\end{array}$ & $\begin{array}{c}\text { Present } \\
\text { ase }\end{array}$ & $\begin{array}{c}\text { Kateg } \\
\text { ori }\end{array}$ \\
\hline 1. & $\begin{array}{c}14- \\
20\end{array}$ & 14 & $31,11 \%$ & $\begin{array}{c}\text { Mamp } \\
\mathrm{u}\end{array}$ \\
\hline 2. & $1-$ & 31 & $68,89 \%$ & $\begin{array}{c}\text { Belum } \\
\text { mamp } \\
\mathrm{u}\end{array}$ \\
\hline
\end{tabular}

Berdasarkan tabel diatas, dapat dilihat bahwa kemampuan siswa dari aspek penulisan irama dalam mengidentifikasi unsur-unsur pembangun teks puisi siswa kelas VIII SMP Negeri Satap 10 Konawe Selatan terdapat 14 orang siswa $(31,11 \%)$ dikategorikan mampu dan 31 orang siswa $(68,89 \%)$ dikategorikan belum mampu.

Selanjutnya untuk mengukur kemampuan siswa dari aspek penulisan irama dalam mengidentifikasi unsur-unsur pembangun teks puisi secara klasikal maka digunakan rumus sebagai berikut.

$$
\begin{aligned}
& K \mathrm{~K}= \\
& \text { Jumlah responden yang memperoleh presentase } \geq 70 \% \\
& \text { Jumlah sampel } \\
& 100 \% \\
& =\frac{14}{45} \times 100 \% \\
& =31,11 \%
\end{aligned}
$$

Dengan demikian, bila dilihat kemampuan siswa pada aspek penilaian, yakni penulisan irama dalam mengidentifikasi unsur-unsur pembangun teks puisi. Kemampuan mengidentifikasi unsur-unsur pembangun teks puisi siswa kelas VIII SMP Negeri Satap 10 Konawe Selatan dikategorikan tidak mampu secara klasikal. Dikatakan belum mampu karena kemampuan siswa hanya mencapai 
$31,11 \%$ atau belum mencapai kriteria kemampuan secara klasikal yang telah ditetapkan yaitu $85 \%$.

\subsubsection{Deskripsi Kemampuan pada Aspek Penulisan Kata Konotasi}

Tabel 4.14

Presentase Perolehan Siswa pada Aspek Penulisan Kata Konotasi dalam Mengidentifikasi Unsur-unsur Pembangun Teks Puisi Siswa Kelas VIII SMP Negeri Satap 10 Konawe Selatan

\begin{tabular}{|c|c|c|c|c|}
\hline $\begin{array}{c}\text { N } \\
\text { o }\end{array}$ & $\begin{array}{c}\text { Sko } \\
\mathbf{r}\end{array}$ & $\begin{array}{c}\text { Frekue } \\
\text { nsi } \\
\text { Siswa }\end{array}$ & $\begin{array}{c}\text { Present } \\
\text { ase }\end{array}$ & $\begin{array}{c}\text { Kateg } \\
\text { ori }\end{array}$ \\
\hline 1. & $\begin{array}{c}14- \\
20\end{array}$ & 3 & $6,67 \%$ & $\begin{array}{c}\text { Mamp } \\
\mathrm{u}\end{array}$ \\
\hline 2. & $\begin{array}{c}1- \\
13\end{array}$ & 42 & $93,33 \%$ & $\begin{array}{c}\text { Belum } \\
\text { mamp } \\
\mathrm{u}\end{array}$ \\
\hline
\end{tabular}

Berdasarkan tabel diatas, dapat dilihat bahwa kemampuan siswa dari aspek penulisan kata konotasi dalam mengidentifikasi unsur-unsur pembangun teks puisi siswa kelas VIII SMP Negeri Satap 10 Konawe Selatan terdapat 3 orang siswa $(6,67 \%)$ dikategorikan mampu secara individual dan 42 orang siswa $(93,33 \%)$ dikategorikan belum mampu.

Selanjutnya untuk mengukur kemampuan siswa dari aspek penulisan kata konotasi dalam menentukan unsurunsur pembangun puisi secara klasikal maka digunakan rumus sebagai berikut

$$
K \mathrm{~K}=
$$

$\underline{\text { Jumlah responden yang memperoleh presentase } \geq 70 \%} \mathbf{X}$

$$
\begin{aligned}
& \text { Jumlah sampel } \\
& 100 \% \\
& =\frac{3}{45} \times 100 \%
\end{aligned}
$$

Dengan demikian, bila dilihat kemampuan siswa pada aspek penilaian, yakni penulisan kata konotasi dalam mengidentifikasi unsur-unsur pembangun teks puisi. Kemampuan mengidentifikasi unsur-unsur pembangun teks puisi siswa kelas VIII SMP Negeri Satap 10 Konawe Selatan dikategorikan tidak mampu secara klasikal. Dikatakan tidak mampu karena kemampuan siswa hanya mencapai $(6.67 \%)$ atau belum mencapai kriteria kemampuan secara klasikal yang telah ditetapkan yaitu $85 \%$.

\subsubsection{Deskripsi Kemampuan pada Aspek Penulisan Kata Berlambang}

Tabel 4.16

Presentase Perolehan Siswa pada Aspek Penulisan Kata Berlambang dalam Mengidentifikasi Unsur-unsur Pembangun Teks Puisi Siswa Kelas VIII SMP Negeri Satap 10 Konawe Selatan

\begin{tabular}{|c|c|c|c|c|}
\hline $\begin{array}{c}\text { N } \\
\text { o }\end{array}$ & $\begin{array}{c}\text { Sko } \\
\mathrm{r}\end{array}$ & $\begin{array}{c}\text { Frekuen } \\
\text { si Siswa }\end{array}$ & $\begin{array}{c}\text { Presenta } \\
\text { se }\end{array}$ & $\begin{array}{c}\text { Katego } \\
\text { ri }\end{array}$ \\
\hline 1. & $\begin{array}{c}14- \\
20\end{array}$ & 10 & $22,22 \%$ & $\begin{array}{c}\text { Mamp } \\
\mathrm{u}\end{array}$ \\
\hline 2. & $\begin{array}{c}1- \\
13\end{array}$ & 35 & $77,78 \%$ & $\begin{array}{c}\text { Belum } \\
\text { mamp } \\
\mathrm{u}\end{array}$ \\
\hline
\end{tabular}

Berdasarkan tabel diatas, dapat dilihat bahwa kemampuan siswa dari aspek penulisan kata berlambang dalam mengidentifikasi unsur-unsur pembangun teks puisi siswa kelas VIII SMP Negeri Satap 10 Konawe Selatan terdapat 10 orang siswa $(22,22 \%)$ dikategorikan mampu secara individual dan 35 orang siswa $(77,78 \%)$ dikategorikan belum mampu.

Selanjutnya untuk mengukur kemampuan siswa dari aspek penulisan kata berlambang dalam menentukan unsur-unsur pembangun puisi secara klasikal maka digunakan rumus sebagai berikut

$$
\begin{gathered}
\text { KK }= \\
\frac{\text { Jumlah responden yang memperoleh presentase } \geq 70 \%}{\text { Jumlah sampel }} \times \\
\begin{array}{c}
100 \% \\
=
\end{array} \\
\frac{10}{45} \times 100 \% \\
=22,22 \%
\end{gathered}
$$

Dengan demikian, bila dilihat kemampuan siswa pada aspek penilaian, yakni penulisan kata berlambang dalam mengidentifikasi unsur-unsur pembangun teks puisi. Kemampuan mengidentifikasi unsur-unsur pembangun teks puisi siswa kelas VIII SMP Negeri Satap 10 Konawe Selatan dikategorikan tidak mampu secara 
klasikal. Dikatakan tidak mampu karena kemampuan siswa hanya mencapai $(22,22 \%)$ atau belum mencapai kriteria kemampuan secara klasikal yang telah ditetapkan yaitu $85 \%$.

\subsubsection{Deskripsi Kemampuan pada Aspek Penulisan Pengimajian}

Tabel 4.18

Presentase Perolehan Siswa pada Aspek Penulisan Pengimajian dalam Mengidentifikasi Unsur-unsur Pembangun Teks Puisi Siswa Kelas VIII SMP Negeri Satap 10 Konawe Selatan

\begin{tabular}{|c|c|c|c|c|}
\hline $\begin{array}{c}\text { N } \\
\text { o }\end{array}$ & $\begin{array}{c}\text { Sko } \\
\mathbf{r}\end{array}$ & $\begin{array}{c}\text { Frekue } \\
\text { nsi } \\
\text { Siswa }\end{array}$ & $\begin{array}{c}\text { Present } \\
\text { ase }\end{array}$ & $\begin{array}{c}\text { Kateg } \\
\text { ori }\end{array}$ \\
\hline 1. & $\begin{array}{c}14- \\
20\end{array}$ & 7 & $15,56 \%$ & $\begin{array}{c}\text { Mamp } \\
\mathrm{u}\end{array}$ \\
\hline 2. & $1-$ & 38 & $84,44 \%$ & $\begin{array}{c}\text { Belum } \\
\text { mamp } \\
\mathrm{u}\end{array}$ \\
\hline
\end{tabular}

Berdasarkan tabel diatas, dapat dilihat bahwa kemampuan siswa dari aspek penulisan pengimajian dalam mengidentifikasi unsur-unsur pembangun teks puisi siswa kelas VIII SMP Negeri Satap 10 Konawe Selatan terdapat 7 orang siswa $(15,56 \%)$ dikategorikan mampu secara individual dan 13 orang siswa $(84,44 \%)$ dikategorikan belum mampu.

Selanjutnya untuk mengukur kemampuan siswa dari aspek penulisan kata berlambang dalam mengidentifikasi unsurunsur pembangun teks puisi secara klasikal maka digunakan rumus sebagai berikut.

$K \mathbf{K}=$

$\underline{\text { Jumlah responden yang memperoleh presentase } \geq 70 \%} \mathbf{X}$ Jumlah sampel $100 \%$

$=\frac{7}{45} \times 100 \%$

$=15,56 \%$

Dengan demikian, bila dilihat kemampuan siswa pada aspek penilaian, yakni penulisan pengimajian dalam mengidentifikasi unsur-unsur pembangun teks puisi. Kemampuan mengidentifikasi unsur-unsur pembangun teks puisi siswa kelas VIII SMP Negeri Satap 10 Konawe
Selatan dikategorikan tidak mampu secara klasikal. Dikatakan tidak mampu karena kemampuan siswa hanya mencapai $(15,56 \%)$ atau belum mencapai kriteria kemampuan secara klasikal yang telah ditetapkan yaitu $85 \%$.

Dari hasil analisis tentang mengidentifikasi unsur-unsur pembangun teks puisi siswa kelas VIII SMP Negeri Satap 10 Konawe Selatan dari setiap penilaian, memperlihatkan nilai persentase yang berbeda-beda. Untuk lebih jelasnya dapat dilihat pada tabel berikut.

Tabel 4.19

Rangkuman Data

\begin{tabular}{|l|c|c|}
\hline $\begin{array}{l}\text { Aspek } \\
\text { Penilaian }\end{array}$ & $\begin{array}{c}\text { Tingkat } \\
\text { Kemampuan }\end{array}$ & Kategori \\
\hline Tema & $55,56 \%$ & $\begin{array}{c}\text { Belum } \\
\text { mampu }\end{array}$ \\
\hline Amanat & $11,11 \%$ & $\begin{array}{c}\text { Belum } \\
\text { mampu }\end{array}$ \\
\hline Rasa & $53,33 \%$ & $\begin{array}{c}\text { Belum } \\
\text { mampu }\end{array}$ \\
\hline Majas & $15,56 \%$ & $\begin{array}{c}\text { Belum } \\
\text { mampu }\end{array}$ \\
\hline Irama & $31,11 \%$ & $\begin{array}{c}\text { Belum } \\
\text { mampu }\end{array}$ \\
\hline $\begin{array}{l}\text { Kata } \\
\text { konotasi }\end{array}$ & $6,67 \%$ & $\begin{array}{c}\text { Belum } \\
\text { mampu }\end{array}$ \\
\hline $\begin{array}{l}\text { Kata } \\
\text { Berlambang }\end{array}$ & $22,22 \%$ & $\begin{array}{c}\text { Belum } \\
\text { mampu }\end{array}$ \\
\hline Pengimajian & $15,56 \%$ & $\begin{array}{c}\text { Belum } \\
\text { mampu }\end{array}$ \\
\hline \multicolumn{2}{|c|}{ Berdasarkan } & deskripsi diatas dapat \\
\hline delapan
\end{tabular}
diinterpretasikan bahwa dari delapan komponen yang menjadi aspek penilaian, Maka aspek kemampuan penulisan tema teks menduduki skor rendah dengan persentase sebesar 55,56\% (belum mampu), diikuti aspek penulisan amanat dengan persentase sebesar 11,11\% (belum mampu), aspek penulisan perasaan penyair dengan persentase sebesar 53,33\% (belum mampu), aspek majas dengan memperoleh persentase $15,56 \%$ (belum mampu), aspek penulisan irama memperoleh persentase sebesar 31,11 (belum mampu), aspek penulisan kata konotasi memperoleh persentase sebesar $6,67 \%$ (belum mampu), aspek penulisan kata berlambang memperoleh persentase $22.22 \%$ 
(belum mampu), dan aspek penulisan pengimajian dengan memperoleh persentase sebesar 15,56\% (belum mampu). Dikatakan belum mampu dalam mengidentifikasi unsur-unsur pembangun teks puisi karena pemahaman siswa yang masih kurang.

Berdasarkan hasil wawancara dengan guru bahasa Indonesia pada tanggal 14 Desember 2019, diketahui bahwa faktor yang mempengaruhi siswa sehingga belum mampu yaitu (1) kurangnya pemahaman atau minat siswa dalam menerima materi tentang unsur-unsur pembangun atau pembentuk puisi, (2) tidak adanya perhatian, kemauan, dan rasa ingin keingintahuan siswa untuk memahami lebih jauh lagi tentang materi unsur-unsur pembangun puisi, meskipun guru telah menjelaskan materi tersebut dan disertakan contoh pada setiap aspek, namun saat ditanya kembali siswa tidak tahu apa yang telah dijelaskan oleh gurunya tadi, sehingga pada saat diberikan soal tentang mengidentifikasi unsur-unsur pembangun teks puisi siswa belum bisa menjawab karena dalam menerima pelajaran ini hanya sekedar mendengarkan. Sedangkan berdasarkan hasil wawancara dengan siswa padat tanggal 15 Desember 2019 diketahui belum mampu dikarenakan (1) siswa kurang mengerti dengan apa yang telah dijelaskan oleh gurunya, (2) kemalasan siswa dalam menerima pelajaran sehingga pada saat ditanya oleh gurunya mengerti atau belum, siswa hanya pura-pura mengerti karena siswa malas bertanya. hal ini juga dapat dilihat dari persentase yang dicapai siswa pada masing-masing aspek indikator penilaian. Dengan hasil yang dicapai tersebut siswa harus lebih giat lagi dalam belajar, terus berkreasi dalam menggali ilmu, agar tujuan pembelajaran dapat tercapai dengan maksimal dan hasil yang diperoleh ditingkatkan lagi.

Berdasarkan hal tersebut, maka perlu meningkatkan kemampuan dalam mengidentifikasi unsur-unsur pembangun teks puisi terutama pada aspek tema, amanat, rasa, majas, irama, kata konotasi, kata berlambang, dan pengimajian, oleh karena itu pihak sekolah perlu menyediakan buku-buku sastra yang memadai. Dengan tersediannya buku atau bahan pembelajaran sastra tersebut siwa dapat dengan mudah dalam mengidentifikasi unsur-unsur pembangun teks puisi maupun unsur-unsur yang membangun karya sastra lainnya. Disamping itu juga guru mata pelajaran bahasa Indonesia perlu melatih dan membimbing siswa secara terus-menerus dalam mengidentifikasi unsur-unsur puisi dengan cara memberikan tugas atau latihan membaca ataupun menulis puisi atau karya sastra lainya dan kemudian dianalisis per aspek yang membangun karya sastra itu sendiri.

\section{KESIMPULAN}

Berdasarkan hasil analisis data yang dilakukan, dapat disimpulkan bahwa siswa kelas VIII SMP Negeri Satap 10 Konawe Selatan yang dijadikan sampel penelitian, secara individual terdapat 21 orang siswa atau $46,67 \%$ berada pada kategori mampu dalam mengidentifikasi unsur-unsur pembangun teks puisi, dan 24 orang siswa atau 53,33\% masuk kategori tidak mampu dalam menentukan unsur-unsur pembangun puisi. Secara klasikal dapat dikatakan bahwa kemampuan mengidentifikasi unsur-unsur pembangun teks puisi siswa kelas VIII SMP Negeri Satap 10 Konawe Selatan masuk kategori tidak mampu. Dikatakan tidak mampu karena siswa yang secara individual mencapai kemampuan minimal $70 \%$ hanya sebesar $46,67 \%$ tidak mencapai kriteria ketuntasan klasikal yaitu $85 \%$.

\subsection{Saran}

Dengan demikian pada kemampuan siswa yang diperhatikan dalam mengidentifikasi unsur-unsur pembangun teks puisi dalam penelitian disarankan sebagai berikut. Berdasarkan hasil penelitian ini penulis memberikan saran sebagai berikut.

1. Guru bahasa Indonesia sebaiknya lebih kreatif dalam pembelajaran bahasa Indonesia dalam teks puisi agar siswa tertarik untuk mengikuti pembelajaran khususnya tentang mengidentifikasi unsur-unsur pembangun teks puisi. 
2. Guru bahasa Indonesia perlu memberikan perhatian khusus kepada siswa yang belum memiliki kemampuan dalam mengidentifikasi unsur-unsur pembangun teks puisi dapat dipahami oleh siswa.

3. Untuk pembelajaran menentukan unsur-unsur pembangun puisi, guru dapat menyesuaikan ketuntasan materi pembelajaran dengan pemahaman siswa sehingga kelulusan aspek-aspek dalam mengidentifikasi unsur-unsur pembangun teks puisi dapat dipahami oleh siswa.

4. Dalam proses pembelajaran sebaiknya perlu dilakukan pemberian latihan-latihan.

\section{DAFTAR PUSTAKA}

Dalman, 2016. Keterampilan Menulis. Jakarta:PT Rajagrafindo Persada.

Juanda, Asep. 2017. Pocket Book Bahasa Indonesia SMP/MTs kelas VII, VIII, \&IX Jakarta:Cmedia.

Komaidi, Didik. 2017. Panduan Lengkap Kreatif Proses, Keterampilan, danProfesi.Yogyakarta: Araska.

Kosasih, E. 2017. Buku Siswa Bahasa Indonesia. Jakarta: Kementrian Pendidikan dan Kebudayaan.

Kosasih, E. 2017. Buku Guru Bahasa Indonesia. Jakarta: Kementrian Pendidikan dan Kebudayaan.

Mahsun, 2014. Teks dalam Pembelajaran Bahasa Indonesia Kurikulum 2013. Jakarta: PT Rajagrafindo Persada.

Mulyadi, Yadi, dkk. 2016. Intisari Sastra Indonesia. Bandung: Yrama Widya.

Nilas, Risha dan Nufus. 2017. Pedoman Umum Ejaan Bahasa Indonesia. Jakarta: PT Wahyu Media.

Purwandari, Retno dan Qoni'ah. 2012. Buku Pintar Bahasa Indonesia. Yogyakarta: Familia

Pradopo, Rachmat Djoko. 2017. Pengkajian Puisi. Yogyakarta: Gadja Mada University Press.
Said, Rahmat. 2017. Penggunaan Bahasa Indonesia yang Benar pada Karya Ilmiah. Kendari: CV. Metro Graphia Kendari

Siswanto, Wahyudi. 2008. Pengantar Teori Sastra. Jakarta: PT Grasindo.

Siswantoro, 2014. Metode Penelitian Sastra. Yogyakarta. Pustaka Pelajaran.

Soebachman, Adiba A. 2016. Mahir Menulis dalam 4 Hari. Yogyakarta: Kauna Pustaka.

Sumardjo,Jakob. 2004. Cacat Tentang Menulis Yogyakarta: Pustaka B

Sugiyono, 2015. Metode Kuantitatif, Kualitatif, Bandung:

Alfabeta.

Tarigan, Henry Guntur. 2013. Mer sebagai Suatu Keteram Berbahasa. Bandung: Angkasa.

Waluyo, J Herman. 2002. Teori a . Apresiasi Puisi. Gelora Aksara Pratama: Erlangga.

Yani , Ahmad, 2014. Minset Kurikulum 2013. Alfabeta: Bandung 